\title{
The Effect of Processing and Storage on Key Enzymes, B Vitamins, and Lipids of Mature Human Milk I. Evaluation of Fresh Samples and Effects of Freezing and Frozen Storage
}

\author{
BEVERLY A. FRIEND, ${ }^{(51)}$ KHEM M. SHAHANI, CAROL A. LONG, AND LINDA A. VAUGHN \\ Department of Food Science and Technology, University of Nebraska, Lincoln, Nebraska, USA
}

\begin{abstract}
Summary
A study was initiated to evaluate the effects of several methods of processing and storage on key enzymes, $B$ vitamins, and lipid components of mature human milk. In order to establish standard values for the nutrient components with which to compare processed samples, a total of $\mathbf{3 0}$ individual raw samples of mature human milk were analyzed. There was considerable sample to sample variation as indicated by the large range of values for each component. Freezing and frozen storage had little effect on the enzymes of pooled samples of milk. Lactoperoxidase activity decreased from 36 in raw pooled samples to 17 in pooled samples slow frozen and stored for 3 months at $-25^{\circ} \mathrm{C}(P<0.05)$. Similarly, quick freezing and storage for 3 months significantly decreased the lactoperoxidase activity of pooled samples from 93 to $14(P<0.05)$. Quick freezing and frozen storage tended to increase lipase activity although the changes were not significant. Freezing and frozen storage did not significantly affect the levels of biotin, niacin, and folic acid. Similarly, the total lipid fatty acid level and relative $\%$ of each fatty acid were not significantly different in the frozen samples as compared to the raw samples.
\end{abstract}

\section{Speculation}

Our data suggest that freezing and frozen storage for up to 3 months can be used to preserve mature human milk with minimum loss of its biologic activity. Slow freezing is more preferable because this method requires less effort and equipment but affords the same storage stability as quick freezing.

Human milk, unlike cow's milk or synthetic formulas, possesses a composition uniquely suited to the needs of the human infant. Although it is difficult to assign a precise nutritional or bacteriostatic role to each milk component, the sum total of these components is responsible for the differences in growth, development and health noted for breast-fed versus bottle-fed infants $(1,9,16$, $31,46)$. The recognition of the superiority of breast milk has led to an increased incidence of breast feeding $(7,28)$, and a renewed interest in establishing human milk banks to serve the needs of premature infants and full-term infants who are ill or who temporarily cannot be breast-fed $(2,39,42,47)$.

Evidence that pasteurization and other methods of preservation not only eliminate bacterial contaminants but also destroy many beneficial milk components, including the immunoglobulins, lysozyme and Lactobacillus bifidus factors $(5,13,14,17,38)$, has led some to suggest that heating of donor milk samples is unnecessary and unadvisable $(2,8,44,47)$. Recent reports of the transmission of salmonellosis (40) and streptococcal disease $(26,41)$ through ingestion of infected breast milk necessitate a careful reexamination of milk banking procedures. Determining the effects that processing and storage have on donated milk samples would allow the establishment of procedures which ensure a bacteriologically safe milk with maximum storage stability and minimal loss of nutrients and biologic activity.

This study was initiated to evaluate the effects of several methods of processing and storage on key enzymes, B vitamins, and lipid components of mature human milk. This paper summarizes the average values and ranges of these nutrients in individual raw milk samples and the effects of freezing and frozen storage on these components. A companion paper (15) summarized the effects of freeze-drying, pasteurization, high heat treatment, and storage.

\section{MATERIALS AND METHODS}

Collection and pooling of breast milk samples. Individual mature milk samples were obtained from donors 10 days to 6 months postpartum. Samples, ranging from $20-80 \mathrm{ml}$, were manually expressed by the donor into sterile glass jars, refrigerated, transported to the laboratory, and then analyzed individually as raw samples or pooled (8-12 samples per pool) for freezing studies. Individual samples were refrigerated up to $24 \mathrm{hr}$ after collection, and pooled samples were held up to $48 \mathrm{hr}$ before analysis or freezing.

Freezing studies. Ten pooled samples of mature milk were used for slow freezing studies and ten for quick freezing studies. Each pooled sample was divided aseptically into four equal portions which were placed in sterile containers. One of the four portions (unfrozen control) was analyzed immediately: for enzymes, B vitamins, and lipids and the other three portions were frozen either by placing in the freezing compartment of a domestic refrigerator at $-25^{\circ} \mathrm{C}$ (slow freeze) or by immersing in a dry ice/acetone/ alcohol bath (quick freeze). Frozen samples were then held at $-25^{\circ} \mathrm{C}$ until analysis for enzyme, $\mathrm{B}$ vitamin, and lipid components at $1 \mathrm{wk}, 1$ month, and 3 months.

Analysis of enzymes, $B$ vitamins, and lipids. Skim milk samples, prepared by centrifugation at $5900 \times g$ for $10 \mathrm{~min}$, were used for analysis of lactoperoxidase, lysozyme, and protease. Whole milk was used for remainder of the analyses. Lactoperoxidase (EC 1.11.1.7) activity was measured spectrophotometrically by the method of Gothefors and Marklund (19). The procedure of Parry et al. (34), which is based on lysis of Micrococcus lysodeikticus cells, was used to quantitate lysozyme (EC 3.2.1.17). Lipase (EC 3.1.1.3) was monitored using a $\mathrm{pH}$ stat according to the procedure of Parry et al. (35). Protease (EC 3.4.4.) activity was measured as described by Kiermeier and Semper (27).

B vitamins were analyzed using microbiologic methods (20). Biotin was assayed by a spectrophotometric method using Lactobacillus plantarum $\# 8014$ as the test organism, niacin by a titrimetric method using L. plantarum \#8014, and pantothenic acid by a titrimetric method using $L$. casei $\# 7469$ as the assay organism.

Total lipids were extracted from the milk using the Roese- 
Gottlieb method (3). The unesterified fatty acid content was determined by titration using a weighed aliquot of the lipid extract (4). Approximately $150 \mathrm{mg}$ of lipid extract were saponified and then reacted with $\mathrm{BF}_{3}$-methanol according to the procedure of Metcalfe et al. (33). The fatty acid methyl esters were extracted with petroleum ether and then separated on a Varian gas chromatograph, Model 1200, equipped with a $6 \mathrm{ft}$ by $1 / 8$ inch stainless steel column packed with $10 \%$ SP-2330 on $100 / 120$ mesh Chromosorb W AW. The column temperature was programmed from $180-230^{\circ} \mathrm{C}$ at $3^{\circ} \mathrm{C} / \mathrm{min}$ with the nitrogen carrier gas flow-rate at $35 \mathrm{ml} / \mathrm{min}$. The area of each fatty acid peak was determined automatically with a Hewlett Packard Model 5840A GC Terminal Integrator, and results were expressed as relative \% of each fatty acid.

\section{RESULTS}

In order to establish standard values for the nutrient components with which to compare processed samples, a total of 30 individual raw samples of mature human milk was analyzed (Table 1). There was considerable sample to sample variation as

Table 1. Enzyme, B vitamin, and lipid content of raw mature breast milk ${ }^{1}$

\begin{tabular}{lcc}
\hline \multicolumn{1}{c}{ Component } & Mean \pm S.D. & Range \\
\hline Enzymes & & \\
Lactoperoxidase $(\Delta \mathrm{OD} / \mathrm{min} / 100 \mathrm{ml})$ & $44 \pm 42$ & $(4-155)$ \\
Lipase $(\mu \mathrm{mole} / \mathrm{min} / 100 \mathrm{ml})$ & $108 \pm 66$ & $(26-311)$ \\
Lysozyme $(\mathrm{mg} / 100 \mathrm{ml})$ & $20 \pm 20$ & $(2-68)$ \\
Protease $(\mu \mathrm{mole} / \mathrm{min} / 100 \mathrm{ml})$ & $0.21 \pm 0.15$ & $(0.02-0.56)$ \\
B vitamins & & \\
Biotin $(\mu \mathrm{g} / 100 \mathrm{~g})$ & $0.87 \pm 0.42$ & $(0.14-1.72)$ \\
Niacin $(\mu \mathrm{g} / 100 \mathrm{~g})$ & $211 \pm 59$ & $(129-348)$ \\
Pantothenic acid $(\mu \mathrm{g} / 100 \mathrm{~g})$ & $297 \pm 137$ & $(132-625)$ \\
Folic acid $(\mu \mathrm{g} / 100 \mathrm{~g})$ & $2.13 \pm 1.59$ & $(0.25-7.88)$ \\
Lipids & & \\
Total lipid $(\mathrm{g} / 100 \mathrm{ml})$ & $2.98 \pm 1.40$ & $(1.06-6.83)$ \\
Unesterified fatty acids $(\mathrm{g} / 100 \mathrm{~g} \mathrm{lipid})$ & $3.8 \pm 15.5$ & $(0.4-14.1)$ \\
$8: 0(\%)$ & $0.24 \pm 0.03$ & $\left(\mathrm{TR}{ }^{2}-0.7\right)$ \\
$10: 0(\%)$ & $1.4 \pm 1.5$ & $(0.2-7.4)$ \\
$12: 0(\%)$ & $4.2 \pm 7.4$ & $(1.6-11.9)$ \\
$14: 0(\%)$ & $5.0 \pm 3.8$ & $(2.4-9.7)$ \\
$16: 0(\%)$ & $19.7 \pm 18.1$ & $(9.9-25.8)$ \\
$16: 1(\%)$ & $1.4 \pm 1.0$ & $(0.2-4.2)$ \\
$18: 0(\%)$ & $9.1 \pm 11.8$ & $(3.5-20.9)$ \\
$18: 1(\%)$ & $40.6 \pm 46.5$ & $(24.2-53.4)$ \\
$18: 2(\%)$ & $14.7 \pm 14.4$ & $(8.6-23.3)$ \\
$18: 3(\%)$ & $1.7 \pm 2.8$ & $(0.7-7.4)$ \\
P/S 3 & $0.41 \pm 0.02$ & $(0.18-0.81)$ \\
\hline 1
\end{tabular}

'All data represent the average of 30 individual samples.

${ }^{2} \mathrm{TR}$, trace (less than $0.2 \%$ ).

${ }^{3} \mathrm{P} / \mathrm{S}$, polyunsaturate/saturate where $\mathrm{P}$ is $18: 2+18: 3$. indicated by the large standard deviation and range of values for each component. Nevertheless, the values fell within established ranges for the lactoperoxidase (19), lipase (10), lysozyme $(10,11$, $37)$, protease $(22,43)$, biotin $(12,23,30)$, niacin $(12,30)$, pantothenic acid $(12,30)$, folic acid (30) and lipids $(6,18,24,25,32)$ of mature human milk.

As shown in Table 2, freezing and frozen storage had little effect on the enzymes of mature human milk. Lactoperoxidase activity decreased during frozen storage and at 6 months the activity was significantly lower $(P<0.05)$ as compared to the raw sample. Quick freezing and frozen storage tended to increase lipase activity although the changes were not significant as compared to the raw sample.

Freezing and frozen storage did not significantly affect the levels of biotin, niacin, and pantothenic acid (Table 3). Similarly the total lipid, unesterified fatty acid level, and relative \% of each fatty acid were not significantly different in the frozen samples as compared to the raw samples (Table 4).

\section{DISCUSSION}

In view of the decreased nutritional value and low antimicrobial activity of pasteurized human milk, it has been suggested that freezing rather than heating be used to preserve breast milk samples $(2,8,21,38,39,44,47)$. As shown in Table 2, frozen storage for up to 3 months after either a slow-freeze or quickfreeze process resulted in a significant decrease $(P<0.05)$ in lactoperoxidase activity and no change in the other enzymes, B vitamins, or lipids. In a similar study, Evans et al. (13) also found that lysozyme was unaffected by storage at $-20^{\circ} \mathrm{C}$ for 3 months.

Table 3. Effect of freezing and frozen storage on B vitamins of mature breast milk

\begin{tabular}{|c|c|c|c|c|}
\hline $\begin{array}{l}\text { Process and stor- } \\
\text { age time }\end{array}$ & $\begin{array}{l}\text { No. of } \\
\text { pooled } \\
\text { samples }\end{array}$ & $\begin{array}{c}\text { Biotin } \\
(\mu \mathrm{g} / 100 \mathrm{~g})\end{array}$ & $\begin{array}{c}\text { Niacin } \\
(\mu \mathrm{g} / 100 \mathrm{~g})\end{array}$ & $\begin{array}{c}\text { Pantothenic } \\
\text { acid } \\
(\mu \mathrm{g} / 100 \mathrm{~g})\end{array}$ \\
\hline Slow Freeze & 8 & & & \\
\hline Unfrozen & & 0.50 & 217 & 332 \\
\hline $\begin{array}{l}\text { Frozen/stored } \\
1 \mathrm{wk}\end{array}$ & & 0.63 & 209 & 312 \\
\hline $\begin{array}{l}\text { Frozen/stored } \\
1 \mathrm{mo}\end{array}$ & & 0.52 & 208 & 276 \\
\hline $\begin{array}{l}\text { Frozen/stored } \\
\quad 3 \mathrm{mo}\end{array}$ & & 0.51 & 212 & 286 \\
\hline Quick Freeze & 7 & & & \\
\hline Unfrozen & & 0.47 & 209 & 273 \\
\hline $\begin{array}{l}\text { Frozen/stored } \\
1 \mathrm{wk}\end{array}$ & & 0.51 & 208 & 286 \\
\hline $\begin{array}{l}\text { Frozen/stored } \\
1 \mathrm{mo}\end{array}$ & & 0.45 & 214 & 277 \\
\hline $\begin{array}{l}\text { Frozen/stored } \\
\quad 3 \mathrm{mo}\end{array}$ & & 0.50 & 213 & 319 \\
\hline
\end{tabular}

Table 2. Effect of freezing and frozen storage on enzymes of mature breast milk

\begin{tabular}{|c|c|c|c|c|c|}
\hline Process and storage time & $\begin{array}{l}\text { No. of pooled } \\
\text { samples }{ }^{1}\end{array}$ & $\begin{array}{c}\text { Lactoperoxidase } \\
(\Delta \mathrm{OD} / \mathrm{min} / 100 \mathrm{ml})\end{array}$ & $\begin{array}{c}\text { Lipase } \\
(\mu \mathrm{mole} / \mathrm{min} / 100 \mathrm{ml})\end{array}$ & $\begin{array}{c}\text { Lysozyme } \\
(\mathrm{mg} / 100 \mathrm{ml})\end{array}$ & $\begin{array}{c}\text { Protease } \\
(\mu \mathrm{mole} / \mathrm{min} / 100 \mathrm{ml})\end{array}$ \\
\hline Slow Freeze & 10 & & & & \\
\hline Unfrozen & & 36 & 95 & 32 & 0.18 \\
\hline Frozen/stored $1 \mathrm{mo}$ & & 26 & 92 & 32 & 0.24 \\
\hline Frozen/stored $3 \mathrm{mo}$ & & $17^{2}$ & 133 & 37 & 0.19 \\
\hline Quick Freeze & 10 & & & & \\
\hline Frozen/stored $1 \mathrm{mo}$ & & 50 & 111 & 21 & 0.15 \\
\hline Frozen/stored $3 \mathrm{mo}$ & & $14^{2}$ & 111 & 18 & 0.12 \\
\hline
\end{tabular}

${ }^{1}$ Each pool consisted of 8-12 individual samples.

${ }^{2}$ Significantly different $(P<0.05)$ from unfrozen control as determined by a paired sample $t$ test. 
Table 4. Effect of freezing and frozen storage on the lipids of mature breast milk

\begin{tabular}{|c|c|c|c|c|c|c|c|c|c|c|c|c|c|}
\hline \multirow{2}{*}{$\begin{array}{c}\text { Process and storage } \\
\text { time }\end{array}$} & \multirow{2}{*}{$\begin{array}{l}\text { Total lipid } \\
(\mathrm{g} / 100 \mathrm{ml})\end{array}$} & \multirow{2}{*}{$\begin{array}{l}\text { Unesterified fatty } \\
\text { acids } \\
\text { (g/100 g lipid) }\end{array}$} & \multicolumn{10}{|c|}{ Fatty acid composition (relative $\%$ ) } & \multirow[b]{2}{*}{$\mathrm{P} / \mathrm{S}^{3}$} \\
\hline & & & $8: 0$ & $10: 0$ & $12: 0$ & $14: 0$ & $16: 0$ & $16: 1$ & $18: 0$ & $18: 1$ & $18: 2$ & $18: 3$ & \\
\hline \multicolumn{14}{|l|}{ Slow Freeze $(10)^{1}$} \\
\hline Unfrozen & 2.49 & 7.7 & $\mathrm{TR}^{2}$ & 0.6 & 3.6 & 5.6 & 25.4 & 1.4 & 9.2 & 38.6 & 4.3 & 1.2 & 0.36 \\
\hline Frozen/stored $1 \mathrm{wk}$ & 2.38 & 7.2 & TR & 0.8 & 4.1 & 6.0 & 23.4 & 1.4 & 9.4 & 38.1 & 14.9 & 1.0 & 0.39 \\
\hline Frozen/stored $1 \mathrm{mo}$ & 2.57 & 8.9 & TR & 0.6 & 3.6 & 5.7 & 23.4 & 1.2 & 10.0 & 40.1 & 14.4 & 0.8 & 0.36 \\
\hline Frozen/stored $3 \mathrm{mo}$ & 2.53 & 8.0 & TR & 0.7 & 4.1 & 6.2 & 24.9 & 1.6 & 9.3 & 38.3 & 13.9 & 0.5 & 0.33 \\
\hline \multicolumn{14}{|l|}{ Quick Freeze $(10)^{1}$} \\
\hline Unfrozen & 2.75 & 6.8 & TR & 0.7 & 4.2 & 5.7 & 20.9 & 1.4 & 9.1 & 41.0 & 16.1 & 0.7 & 0.42 \\
\hline Frozen/stored $1 \mathrm{wk}$ & 2.53 & 10.9 & TR & 0.6 & 3.9 & 5.3 & 23.1 & 1.2 & 9.5 & 40.0 & 15.4 & 0.9 & 0.36 \\
\hline Frozen/stored $1 \mathrm{mo}$ & 2.73 & 7.1 & TR & 0.7 & 4.1 & 5.9 & 24.7 & 1.2 & 9.1 & 38.1 & 15.1 & 0.9 & 0.39 \\
\hline Frozen/stored $3 \mathrm{mo}$ & 2.51 & 11.5 & TR & 0.6 & 4.3 & 5.8 & 23.9 & 1.2 & 8.9 & 39.1 & 15.8 & 0.5 & 0.38 \\
\hline
\end{tabular}

' Number of pooled samples analyzed.

${ }^{2} \mathrm{TR}$, trace (less than $0.2 \%$ ).

${ }^{3} \mathrm{P} / \mathrm{S}$, polyunsaturate/saturate where $\mathrm{P}$ is $18: 2+18: 3$.

During storage, there appeared to be a progressive increase in the activity of lipase (Table 2) and elevation in the level of unesterified fatty acids (Table 4), indicating that spontaneous lipolysis was occurring in the milk. The evidence of lipolysis was most pronounced in the quick-frozen samples stored 3 months. Tarassuk et al. (45) noted that human milk lipase may be activated at low temperatures resulting in significant lipolysis in refrigerated samples of raw breast milk. It is possible a similar process was occurring in the frozen samples.

Several authors $(8,13,17,29,36,44,48)$ have reported that the breast milk leucocytes and immunoglobulins decrease with freezing, resulting in a gradual loss of the milk's antibacterial activity during prolonged storage $(17,21)$; however, the effects of frozen storage are insignificant compared to those caused by pasteurization or sterilization $(5,13,14,17,38)$. Our data also suggest that slow freezing offers the same storage stability as quick freezing with much less effort and equipment and thus would be the method of choice for preserving the milk. A comprehensive program of donor screening, proper aseptic collection, immediate freezing of samples and routine quality control must also be established and enforced in order to ensure microbiologic safety in any unheated samples $(13,39,42,44,47)$.

\section{REFERENCES AND NOTES}

1. American Academy of Pediatrics. Committee on Nutrition: Breast-feeding. Pediatrics. 62: 591 (1978).

2. American Academy of Pediatrics. Committee on Nutrition: Human milk banking. Pediatrics, 65: 854 (1980).

3. AOAC: in Horowitz, W., editor: Official Methods of Analysis. Washington, D.C. 1975 , p. 258.

4. American Oil Chemists' Society, comps: Method Cd-3a-63, in: Official and Tentative Methods, Champaign, IL, 1973.

5. Baum, J. D.: The effect of pasteurization on immune factors in human milk, in: Visser, H. K. A., editor: Nutrition and Metabolism of the Fetus and Infant. p. 273. Martinus Nijhoff Boston, 1979, Martinus Nijhoff Pub., p. 273.

6. Belavady, B.: Lipid and trace element composition of human milk. Acta Paediatr. Scand., 67: 566 (1978)

7. Biering-Sorensen, F., Hilden, J. and Biering-Sorensen, K.: Breast-feeding on the increase. J. Trop. Pediatr., 26: ii (1980)

8. Bjorksten, B., Burman, L. G., De Chateau, P., Fredrikzon, B., Gothefors, L., and Hernell, $\mathrm{O}$ : Collecting and banking human milk: to heat or not to heat? $\mathrm{Br}$ Med. J.. 281: 765 (1980).

9. Blanc, B.: Biochemical aspects of human milk-comparison with bovine milk, in: Bourne, G. H., editor: World Review of Nutrition and Dietetics, Vol. 36. (Basel, Switzerland, 1981, S. Karger, p. 1.

10. Chadau, R. C., Parry, R. M. and Shahani, K. M.: Lysozyme, lipase and ribonuclease in milk of various species. J. Dairy Sci., S1: 606 (1968).

11. Chandan, R. C., Shahani, K. M. and Holly, R. G.: Lysozyme content of human milk. Nature, 204: 76 (1964)

12. Department of Health and Social Security: The composition of mature human milk, in: Report on Health and Social Subjects No. 12, London, 1977, Her Majesty's Stationery Office.

13. Evans, T. J., Ryley, H. C., Neale, L. M., Dodge, J. A., and Lewarne, L. M. Effect of storage and heat on the antimicrobial proteins in human milk. Arch. Dis. Child. 53: 239 (1978)

14. Ford, J. E., Law, B. A., Marshall, V. M. E. and Reiter, B.: Influence of the heat treatment of human milk on some of its protective constituents. J. Pediatr:, 90: 29 (1977).

15. Friend, B. A., Shahani, K. M., Long, C. A., and Agel, E. N.: The effects of processing and storage on key enzymes, B-vitamins and lipids of mature human milk. II. Evaluation of freeze-drying, pasteurization, high heat treatment and storage. J. Food Protect. (In Press).

16. Frier, S. and Eidelman, A. I., Comps: Human Milk. Its Biological and Social Value. Amsterdam, Holland, 1980. Excerpta Medica.

17. Gibbs, J. H., Fisher, C., Bhattacharya, S., Goddard, P. and Baum, J. D.: Drip breast milk: its composition, collection and pasteurization. Early Human Devel., 1: 227 (1977).

18. Gibson, R. A. and Kneebone, G. M.: Fatty acid composition of human colostrum and mature breast milk. Am. J. Clin. Nutr. 34: 252 (1981)

19. Gothefors, L. and Marklund, S.: Lactoperoxidase activity in human milk and in saliva of newborn infant. Infect. Immun. 11: 1210 (1975).

20. Gregory, M. E., Ford, J. E., and Kon, S. K.: The B-vitamin content in milk in relation to breed of cow and stage of lactation. J. Dairy Sci., 25: 447 (1958).

21. Hernandez, J., Lemons, P., Lemons, J. and Todd, J.: Effect of storage processes on the bacterial growth-inhibiting activity of human breast milk. Pediatrics, 63: 597 (1979).

22. Heyndrickx, G. V.: Further investigations on the enzymes in human milk. Pediatrics, 31: 1019 (1963)

23. Hood, R. L. and Johnson, A. R.: Supplementation of infant formulations with biotin. Nutr. Rep. Intl., 21: 727 (1980).

24. Jansson, L., Akesson, B. and Holmberg, L.: Vitamin E and fatty acid composition of human milk. Am. J. Clin. Nutr., 34: 8 (1981).

25. Jensen, R. G., Clark, R. M. and Ferris, A. M.: Composition of lipids in human milk: a review. Lipids, 15: 345 (1980).

26. Kenny, J. F. and Zedd, A. J.: Recurrent group B streptococcal disease in an infant associated with the ingestion of infected mother's milk. J. Pediatr., 91: 158 (1977):

27. Kiermeier, F. and Semper, G.: Uber das Vorkommen eines proteolytischen Enzyms und eines Trypsin-Inhibitors in kumilch. Z. Lebensmitt. Untersuch., I11: 282 (1960)

28. Knodel, J.: Breast-feeding and population growth. Science 198: 1111 (1977).

29. Liebhaber, M., Lewiston, N. J., Asquith, M. T., Olds-Arroyo, L. and Sunshine, P.: Alterations of lymphocytes and of antibody content of human milk after processing. J. Pediatr., 91: 897 (1977).

30. Macy, I. G., and Kelly, H. J.: Human milk and cow's milk in infant nutrition, in Kon, S. K. and Courie, A. T., editors: Milk. The Mammary Gland and Its Secretion, Vol. II, New York, 1961, Academic Press, p. 265.

31. Mata, L.: Breast-feeding: main promoter of infant health. Am. J. Clin. Nutr., 31: 2058 (1978)

32. Mellies, M. J., Ishikawa, T. T., Gartside, P. S., Burton, K., MacGee, T., Allen, K., Steiner, P. M., Brady, D. and Glueck, C. J.: Effects of varying maternal dietary fatty acids in lactating women and their infants. Am. J. Clin. Nutr., 32: 299 (1979).

33. Metcalfe, L. C., Schmitz, A. A. and Pelka, J. R.: Rapid preparation of fatty acid esters from lipids for gas chromatographic analysis. Anal. Chem.; 38: 514 (1966).

34. Parry, R. M., Chandan, R. C. and Shahani, K. M.: A rapid and sensitive assay for muramidase. Proc. Soc. Exp. Biol. Med., 119: 384 (1965).

35. Parry, R. M., Chandan, R. C. and Shahani, K. M.: A rapid and sensitive assay for milk lipase. J. Dairy Sci., 49: 356 (1966).

36. Paxson, C. L. and Cress, C. C.: Survival of human milk leucocytes. J. Pediatr., 94: 61 (1979).

37. Peitersen, B., Bohn, L. and Andersen, H.: Quantitative determination of immunoglobulins, lysozyme and certain electrolytes in breast milk during the entire period of lactation, during a 24-hour period, and in milk from the individual mammary gland. Acta Paediatr. Scand., 64: 709 (1975).

38. Raptopoulou-Gigi, M., Marwick, K. and McClelland, D. B. L.: Antimicrobial proteins in sterilized human milk. Brit. Med, J., 1: 12 (1977).

39. Roy, C. C. and Lescop, J.: Human milk banking. Am. J. Dis. Child., 133: 255 (1979). 
40. Ryder, R. W., Crosby-Richie, A., McDonough, B., and Hall, W. J.: Human milk contaminated with Salmonella kottbus. J. Am. Med. Assoc., 238: 1533 (1977).

41. Schreiner, R. L., Coates, T. and Schackelford, P. G.: Possible breast milk transmission of group B streptococcal infection. J. Pediatr., 91: 159 (1977).

42. Siimes, M. A. and Hallman, N.: A perspective on human milk banking. $\mathbf{J}$. Pediatr., 94: 173 (1979).

43. Storrs, A. B. and Hull, M. E.: Proteolytic enzymes in human and cow milk. J. Dairy Sci., 39: 1097 (1956).

44. Sunshine, P.: Human breast milk--storage and safety considerations: protective effects. West J. Med., 132: 61 (1980).

45. Tarassuk, N. P., Nickerson, T. A. and Yaguchi, M.: Lipase action in human milk. Nature, 201: 298 (1964).

46. Welsh, J. K. and May, J. T.: Anti-infective properties of breast milk. J. Pediatr., 94: 1 (1979).

47. Williamson, S., Hewitt, J. H., Finucane, E. and Gamsu, H. R.: Organization of bank of raw and pasteurized human milk for neonatal intensive care. Brit. Med. J., 1: 393 (1978).

48. Young, F. S. H., Heicher, D. A., Uemura, H. S. andSia, C. C. J.: The effects of freezing and pasteurization on human milk. Hawaii Med. J., 38: 330 (1979).

49. The skillful assistance of Janet Greenwald and Clara Zoz is greatly appreciated.

50. Published as paper 6646, Journal Series, Agricultural Experiment Station, Lincoln, NE. Research was conducted under the Nebraska Agricultural Experiment Station Project 16-032, and supported in part by NIH/NICHD Grant No. 5 RO1 HD12457.

51. Requests for reprints should be addressed to: Dr. Beverly A. Friend, Department of Food Science and Technology, 133 Filley Hall, University of Nebraska, Lincoln, NE 68583-0919.

52. Received for publication October 23, 1981

53. Accepted for publication April 29, 1982. 